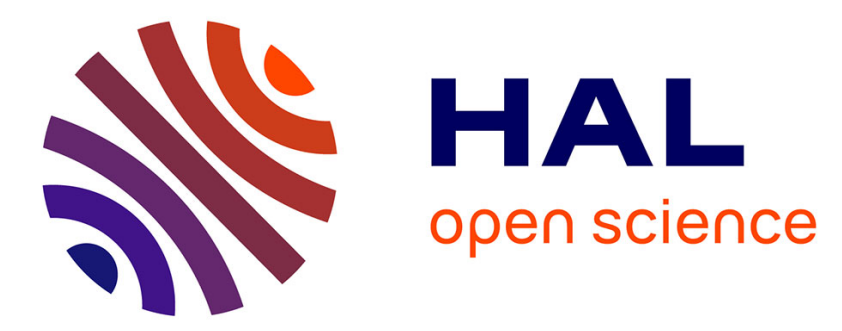

\title{
Should payment for performance depend on mortality?
}

Philippe Loirat, Marie Ferrua, Benoît Lalloué, Aude Fourcade, Etienne

\author{
Minvielle
}

\section{To cite this version:}

Philippe Loirat, Marie Ferrua, Benoît Lalloué, Aude Fourcade, Etienne Minvielle. Should payment for performance depend on mortality? BMJ, 2016, 353, 10.1136/bmj.i3429 . hal-01432907

\section{HAL Id: hal-01432907 \\ https://hal.science/hal-01432907}

Submitted on 12 Jan 2017

HAL is a multi-disciplinary open access archive for the deposit and dissemination of scientific research documents, whether they are published or not. The documents may come from teaching and research institutions in France or abroad, or from public or private research centers.
L'archive ouverte pluridisciplinaire HAL, est destinée au dépôt et à la diffusion de documents scientifiques de niveau recherche, publiés ou non, émanant des établissements d'enseignement et de recherche français ou étrangers, des laboratoires publics ou privés. 


\title{
Should payment for performance depend on mortality?
}

\author{
Philippe Loirat medical adviser, Marie Ferrua researcher, Benoît Lalloué researcher, Aude Fourcade \\ researcher, Etienne Minvielle professor
}

Health Care Management Unit EA 7348 MOS-EHESP, Gustave Roussy, 114, Rue Édouard-Vaillant, 4805 Villejuif, France

The introduction of the Hospital Value Based Purchasing (HVBP) programme, as shown recently by Jose F Figueroa and colleagues, ${ }^{1}$ did not improve 30 day mortality of Medicare beneficiaries admitted to US hospitals for three incentivised conditions. We agree with the authors' conclusion that an "appropriate mix of quality metrics and incentives to improve patient outcomes" has yet to be identified.

The programme was designed to promote better clinical outcomes for hospital patients and to improve their experience of care during hospital stays. ${ }^{2}$ However, if reducing mortality was the primary objective, a specific set of indicators should have been selected from relevant practice and organisational guidelines, which was not the case when the programme was designed. The absence of HVBP's impact on mortality is therefore not surprising.

In their conclusion Figueroa and colleagues say, "Nations considering similar pay for performance programs may want to consider alternative models." This raises a question: should payment depend on achieving a decrease in mortality rates? The primary objective of pay for performance programmes could still be the development and maintenance of continuous quality improvement (CQI) programmes based on relevant process indicators to assess critical steps in patient management, such as the effective use of checklists in surgical procedures. ${ }^{3}$ These process indicators are apt to detect dangerous misconduct, less susceptible to bias, and more actionable.

However, a problem remains: such CQI programmes in hospitals rely on a limited number of people repeatedly trying to motivate a large number of health professionals who are insensitive to the benefits of CQI. Instead of diverting the small percentage of budget devoted to pay for performance programmes it could be more profitable, for patients, to think of a better use for this money.

Competing interests: None declared.

Figueroa JF, Tsugawa $Y$, Zheng J, Orav EJ, Jha AK. Association between the Value-Based Purchasing pay for performance program and patient mortality in US hospitals: observational study. BMJ 2016;353:i2214. doi:10.1136/bmj.i2214 pmid:27160187. 2 QualityNet. Hospital Value Based Purchasing overview. www.qualitynet.org/dcs/ ContentServer?C=Page\&pagename=QnetPublic\%2FPage\%2FQnetTier2\& $\mathrm{cid}=1228772039937$

3 Fourcade A, Blache J Grenier C, Bourgain Jh, Minvielle E. Barriers to staff adoption of a surgical safety checklist. BMJ Qual Saf 2012;21:191-7. doi:10.1136/bmjqs-2011. 000094 pmid:22069112.

Published by the BMJ Publishing Group Limited. For permission to use (where not already granted under a licence) please go to http://group.bmj.com/group/rights-licensing/ permissions 